\title{
Estrogen and progesterone receptor expression in HPV-positive and HPV-negative cervical carcinomas
}

\author{
ANNA KWASNIEWSKA ${ }^{1}$, KRZYSZTOF POSTAWSKI ${ }^{2}$, \\ ANNA GOZDZICKA-JOZEFIAK ${ }^{3}$, WOJCIECH KWASNIEWSKI ${ }^{4}$, EWELINA GRYWALSKA ${ }^{4}$, \\ MALGORZATA ZDUNEK ${ }^{5}$ and ELZBIETA KOROBOWICZ ${ }^{5}$
}

\author{
${ }^{1}$ Department of Obstetrics and Gynecology, Medical University of Lublin, 20-081 Lublin; \\ ${ }^{2}$ Department of Gynaecological Surgery, Medical University of Lublin, 20-954 Lublin; ${ }^{3}$ Department of Molecular Virology, \\ Adam Mickiewicz University of Poznan, 61-614 Poznan; ${ }^{4}$ Department of Clinical Immunology and \\ Immunotherapy, Medical University of Lublin, 20-093 Lublin; ${ }^{5}$ Deparment of Pathomorphology, \\ Medical University of Lublin, 20-954 Lublin, Poland
}

Received December 21, 2010; Accepted February 1, 2011

DOI: $10.3892 / o r .2011 .1256$

\begin{abstract}
Human papillomavirus (HPV) is widely accepted as the main cause of cervical cancer. However, the presence of HPV DNA does not inescapably lead to the development of the cancerous phenotype of the infected cell. Therefore, it is considered that the induction of full cancerous expression of HPV requires additional cofactors. The aim of this study was to assess the expression of estrogen receptor $\alpha(E R \alpha)$ and progesterone receptor (PR) in archived tissue blocks of squamous cell carcinoma and adenocarcinoma of the uterine cervix and to ascertain whether expression of these receptors is associated with the presence of HPV DNA. The investigation was performed using formalin-fixed, paraffin-embedded cervical cancer specimens obtained from 250 women who underwent surgery for histologically confirmed neoplastic lesions. The control group consisted of normal cervical tissues obtained from 50 patients who underwent myomectomy. The results of this study revealed that the expression of ER and PR in planoepithelial cancers and adenocarcinomas of the cervix were decreased to undetectable levels. Only in singular cases in the pattern of staining the expression of ER and PR was noted. In stromal cells of the tested neoplasms, higher expression of both types of receptors was found. Comparison of the expression of ER and PR in the staining pattern and stroma of both squamous cell carcinoma and adenocarcioma of the cervix, showed statistically higher expression in the stromal cells. Strong expression $(+1,+2,+3)$ of ER and PR was noted in the
\end{abstract}

Correspondence to: Professor Anna Kwasniewska, Department of Obstetrics and Gynecology, Medical University of Lublin, Staszica 16 Street, 20-081 Lublin, Poland

E-mail: anna.kwasniewska@am.lublin.pl

Key words: estrogen receptor, progesterone receptor, cervical cancer, human papillomavirus stromal cells irrespective of HPV infection, histopathological type of cancer, and clinical and histopathological grade.

\section{Introduction}

Human papillomavirus (HPV), a sexually transmitted DNA virus, is widely accepted as the main cause of cervical cancer $(1,2)$. However, the presence of HPV DNA does not inescapably lead to the development of the cancerous phenotype of the infected cell. This has been confirmed by many clinical observations, as not all HPV-positive women develop cervical cancer (3-5). Therefore, it is believed that the induction of full cancerous expression by HPV requires additional cofactors.

Studies of the genome of anogenital papilloma viruses have revealed the presence of virus sequences (LCR, long control region) $(6,7)$, capable of binding receptors of steroid hormones. The featured sequences have a configuration of elements that respond to the glucocorticoid receptor and the progesterone receptor (PR) (8). To date, no response elements to the estrogen receptor (ER) have been found in the regulatory region of the virus. However, in the genome of HPV-16 seven different regions of high resemblance to ER sequences have been discovered. Dimers of steroid receptors are formed by combining with ligands and become active forms. After binding with DNA sequences in the promoter regulatory region, they function as transcription factors that regulate the expression of genes (3). Hence, variable plasma concentrations of hormones during their uncontrolled reception or hormone disorders can result in the increased gene expression of HPV-16 and -18 (9-11), the two HPV subtypes most commonly associated with cervical cancer (12). In addition, most cases of cervical cancer arise in the transformation zone, the most estrogen-sensitive region of the cervix $(13,14)$.

In recent years, the results of epidemiological research, particularly those which demonstrate the higher risk of developing cervical cancer as a result of long-term oral contraceptive use are alarming (15-17). A study by Moreno et al (16), performed on behalf of the IRAC Word Heath Organization, 
and a meta-analysis carried out by Smith et al (17) found that long-term oral contraceptive usage can increase the risk of the incidence of cervical cancer up to 4 times, particularly in women with persistent HPV infection (15-17). Research conducted by Salazar et al (18) revealed that cervical carcinomas in women using oral contraceptives, had higher levels of the ER than the those in women who had not taken estrogen-containing oral contraceptives.

The findings of molecular research investigating the interaction between estrogen, progesterone and HPV infection are less divergent than the epidemiological results. A number of investigations have been performed using in vitro models. Arbeit et al (19) found direct hormonal activation of the viral genome in K14 promoter-HPV transgenic mice, in which exogenous estrogen exposure induced multistage neoplastic progression in the squamous epithelium of the cervix and vagina in $100 \%$ of transgenic mice. Thus, estrogen appears to contribute to the persistence of HPV infections and subsequent neoplastic progression by increased viral gene expression. Women who expressed higher levels of ER transcripts were significantly more likely to have cervical HPV infection. However, a recent study showed that E7 oncoprotein and exogenous estrogen failed to promote atypical squamous metaplasia in the absence of ER $\alpha$ suggesting that this receptor plays a crucial role at an early stage of cervical carcinogenesis in mouse models (20).

Steroid hormones achieve their biological effect through receptors. Current research indicates the existence of two types of estrogen receptors, ER $\alpha$ and ER $\beta(21,22)$ and several isoforms of both receptors $(23,24)$. ERs are coded by genes located in different chromosomes (correspondingly 6 and 11), and their expression is altered in target tissues. Usually, both types of receptors exist simultaneously, although type $\alpha$ is predominant in the breast, corpus and uterine cervix and in the vagina, whereas type $\beta$ is prevalent in the ovaries, prostate, testis and lungs (24). Both receptors are present in the central nervous, cardiovascular and osseous systems $(24,25)$. PR exists as two isoforms, which differ in the size of the protein molecule. PR B is 164 amino acids longer than PR A. The difference in the length of the PR isoforms is due to the site of initiation of transcription on the gene. In the case of the shorter form (PR A) the initiation of transcription starts between nucleotide 737 and 842 . This difference has no influence on the relationship of the PR to its ligands. The only difference in biological activity is the presence of an additional activation function (AF-3 activation function) (26).

The aim of this study was to assess the expression of ER $\alpha$ and PR in archived tissue blocks of squamous cell carcinoma and adenocarcinoma of the uterine cervix which were obtained from patients who underwent tumor resection and to ascertain whether expression of these receptors is associated with the presence of HPV DNA.

\section{Materials and methods}

Materials. The investigation was performed using formalinfixed, paraffin-embedded cervical cancer specimens obtained from 250 women who underwent surgery during the period 1998-2008 at the Department of Gynecological Surgery of Lublin County for histologically confirmed neoplastic lesions.
The Local Ethics Committee of the Medical University of Lublin approved the research protocol. The study material was obtained from patients presenting with i) cervical carcinoma (histopathological finding, squamous cell carcinoma and adenocarcinoma of the uterine cervix) and ii) uterine myoma (histopathological finding, leiomyoma uteri). The control group consisted of normal cervical tissues obtained from 50 patients who underwent myomectomy.

The histopathological criteria of the World Health Organization (WHO) were used to establish the diagnosis of cervical carcinoma (27). Fig. 1 illustrates hematoxylin and eosin staining for carcinoma in situ of the uterine cervix. Of the squamous cell carcinoma cases, the histopathological types included 130 cases of keratinized type and 70 cases of non-keratinized type (Fig. 2). Of the 50 patients with adenocarcinoma of the cervix, 25 cases of mucinous type, 10 cases of endometrioid type, 8 cases of clear-cell type, 4 cases of serous type and 1 case of mesonephric type were noted.

According to the degree of dedifferentiation of the neoplastic cells, the cases were grouped as follows: well-differentiated (G1) carcinomas (89 squamous cell carcinomas and 15 adenocarcinomas), moderately differentiated (G2) carcinomas (78 squamous cell carcinomas and 18 adenocarcinomas), and poorly differentiated (G3) carcinomas (83 squamous cell carcinomas and 17 adenocarcinomas). According to the FIGO clinical staging (28), 150 patients were classified as having stage I and 100 as having stage IIA disease. There were no significant differences in the average age of women who underwent surgery for planoepithelial cervical cancer when compared to the control women ( $45.67 \pm 35.49$ vs. $45.94 \pm 6.12$ years).

Methods. Paraffin blocks of tissue fixed in $10 \%$ buffered formalin were cut into two or three sections $(4 \mu \mathrm{m})$. The microtome was rinsed with alcohol before cutting each block. A new cutting blade was used for the cutting of each of the paraffin blocks. The pieces obtained in this manner were placed in a $1.5 \mathrm{-ml}$ testing tube with polypropylene, and the paraffin was removed using xylene at a temperature of $37^{\circ} \mathrm{C}$ for $30 \mathrm{~min}$. They were centrifuged twice at $6000 \mathrm{rpm}$ for $3 \mathrm{~min}$, rinsed twice in $1 \mathrm{ml}$ of absolute alcohol for $30 \mathrm{~min}$ and air dried. After removal of the paraffin, the pieces were homogenized with the addition of $1 \mathrm{ml}$ Hirt buffer having the following composition: $0.01 \mathrm{M}$ Tris-HCI (pH 7.5), $0.01 \mathrm{M}$ EDTA, $0.6 \%$ SDS.

The homogenate was incubated for $30 \mathrm{~min}$ at room temperature. $\mathrm{K}$ proteinase was then added reaching a final concentration of $50 \mu \mathrm{g} / \mathrm{ml}$, and incubation was carried out for $24 \mathrm{~h}$ at $37^{\circ} \mathrm{C}$. After incubation, half the volume of phenol:chloroform:isoamyl alcohol (in a ratio of 25:24:1) mixture was added to the solution; it was shaken for $15 \mathrm{~min}$ at room temperature and centrifuged for $15 \mathrm{~min}$ at $3000 \mathrm{rpm}$. Half the volume of phenol, chloroform, isoamyl alcohol mixture was again added to the obtained water phase. This was shaken energetically and subsequently centrifuged. The above steps were repeated until complete purification of DNA manifested by the lack of interphase. Then, half the volume of isopropylene alcohol and 0.1 volume of $3 \mathrm{M}$ acetate with $\mathrm{pH} 7.0$ was added to the water phase.

The DNA samples obtained in this manner were then rinsed in $80 \%$ ethanol and dissolved in distilled water after drying. The samples with dissolved DNA were stored at $-20^{\circ} \mathrm{C}$. Quantitative determination of the DNA obtained was carried out spectropho- 


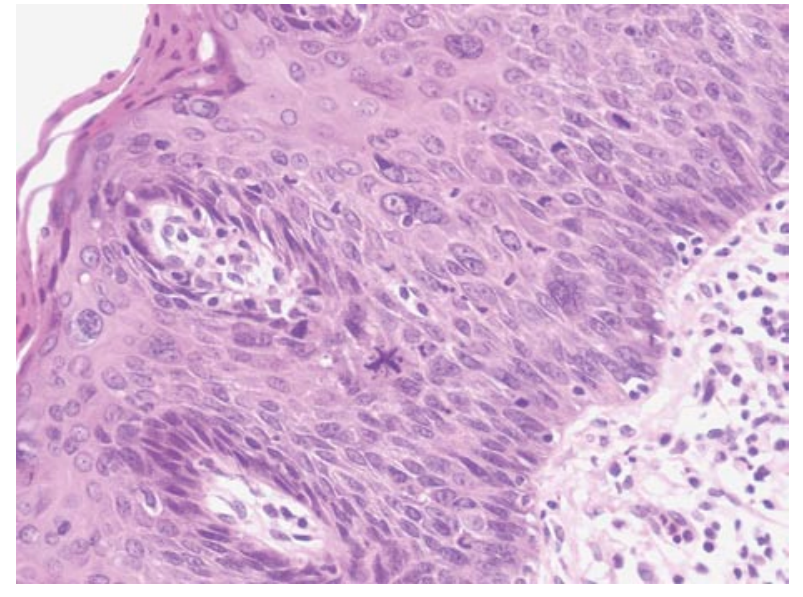

Figure 1. Carcinoma in situ of the uterine cervix. H\&E. Magnification, $\mathrm{x} 400$.

tometrically using an automatic spectrophotometer (Amersham Pharmacia Co.). In order to determine the amount of DNA in a given sample, $1 \mu 1$ of the sample was dissolved in $69 \mu 1$ of re-distilled water and, after calibration of the spectrophotometer, placed in its measuring chamber. After automatic processing of the measured data, the results were recorded in $\mu \mathrm{g} / \mathrm{ml}$.

HPV-PCR identification. In order to identify viral genome incorporated into cancerous DNA, polymerase chain reaction (PCR) was used to recognize HPV types 16 or 18. Identification of the HPV types was performed using consensus PCR primers for L1: MY09: 5'-CGTCCMARRGGAWACTGATC-3' and MY11: 5'-GCMCAAGGWCATAAYAATGG-3' where $\mathrm{M}=\mathrm{A}+\mathrm{C}, \mathrm{R}=\mathrm{A}+\mathrm{G}, \mathrm{W}=\mathrm{A}+\mathrm{T}, \mathrm{Y}=\mathrm{C}+\mathrm{T}$. This set of primers amplifies DNA of at least 33 different HPV genotypes.

Identification of HPV types 16 and/or 18 was performed using the fallowing type-specific PCR primers: HPV-16/L1A/ HPV-16/L1B, 5'-GCCTGTGTAGGTGTTGAGGT-3' and 5'-TGGATTTACTCCAACATTGG-3' (product size 264 bp); HPV-18/L1A/HPV-18/L1B, 5'-GTGGACCAGCAAATACA GGA-3' and 5'-TGCAACGACCACGTGTTGGA-3' (product size 162 bp); HPV-18ME12/HPV-18ME50/E6, 5'-CACGGC GACCCTACAAGCTACCTG-3' and 5'-TGCAGCACGAATT GGCACTGGCCTC-3' (product size 404 bp).

The total volume $(10 \mu \mathrm{l})$ of PCR mixture contained $1 \mu \mathrm{M}$ of primers, $200 \mu \mathrm{M}$ deoxynucleotide triphosphate, $1 \mathrm{X}$ PCR buffer (0.1 M Tris- $\mathrm{HCl} \mathrm{pH} 8.8,0.5 \mathrm{M} \mathrm{KCl}, 0.015 \mathrm{M} \mathrm{MgCl}_{2}$, $1 \%$ Triton $\mathrm{X}-100)$, the investigated DNA (10 $\mathrm{ng} / \mu \mathrm{l})$ and Tag polymerase at a final concentration of $40 \mathrm{U} / \mathrm{ml}$. After preliminary denaturation $\left(15 \mathrm{~min}\right.$ at $\left.94^{\circ} \mathrm{C}\right)$ samples were amplified for 31 cycles in a thermal cycler. Each cycle consisted of the following steps: denaturation at $94^{\circ} \mathrm{C}$ for $30 \mathrm{sec}$, annealing at $59^{\circ} \mathrm{C}$ for $30 \mathrm{sec}$ followed by primer extension at $72^{\circ} \mathrm{C}$ for $1 \mathrm{~min}$. In the last PCR cycle, the stage of complementary DNA synthesis at $72^{\circ} \mathrm{C}$ was extended to $420 \mathrm{sec}$. PCR products were analyzed using agarose gel electrophoresis in the presence of pBluescript DNA digested with HindI.

Immunohistochemical (IHC) analysis of the expression of $E R$ and $P R$. The monoclonal mouse antibody $\operatorname{IgG1}$ class (Novocastra) against the epitope characteristic for ER $\alpha$ protein

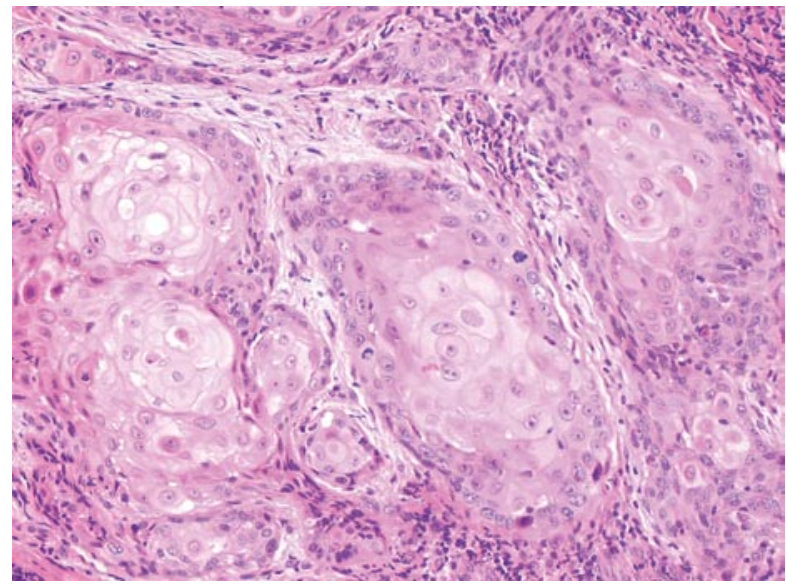

Figure 2. Squamous cell carcinoma (well differentiated) of the cervix, keratinizing type. H\&E. Magnification, $x 400$.

was used for IHC analysis (ER, cat. no. NCL-L-ER-6F11). Prokaryotic recombinant protein corresponding to the full length ER $\alpha$ molecule was the antigen used for immunization.

The monoclonal mouse antibody class $\mathrm{IgG}_{1}$ against PR protein was used for IHC study of the PR recombinant protein corresponding to the $\mathrm{N}$-terminal region of the PR A form which was the antigen used for immunization.

$\mathrm{IgG}_{1}$ antibodies (DakoCytomation; cat. no. X0931) were used as a positive and negative control standard. For deparaffinization, the rehydrated slides were placed in a thermostat at $37^{\circ} \mathrm{C}$, overnight. The next day the slides were deparaffinized in xylene and passed through graded alcohols to distilled water. The antigens were unmasked in $0.01 \mathrm{M}$ citrate buffer (pH 6.0) using a microwave oven for three cycles for $5 \mathrm{~min}$. After $20 \mathrm{~min}$, the tissue sections were placed in Tris buffer with $\mathrm{NaCl}(\mathrm{pH}$ 7.6) at room temperature. The staining was performed in an autostainer (DAKO automated immunostainer) utilizing a staining system. Sections were then washed with $0.3 \%$ solutions of hydrogen peroxidate $\left(\mathrm{H}_{2} \mathrm{O}_{2}\right)$ for $5 \mathrm{~min}$. After rising in TBS buffer, the slides were incubated for $1 \mathrm{~h}$ with the appropriate primary antibody against ER (dilution 1:50; clone 6F11, Novocastra) and against PR (dilution 1:100; clone 1A6, Novocastra). The Vectastain Elite ABC Kit was used as the detection system (Vector Laboratories, USA). The DAB Substrate kit (Vector Laboratories) was used as a chromogen. Subsequently, all sections were counterstained with Mayer's hematoxylin and mounted with Canadian balm.

IHC evaluation of the expression of the studied ER and PR proteins was performed independently by two pathomorphologists. The distribution of nuclear staining for ER and PR was evaluated for each section. The number of positive cells were counted under $\times 200$ magnification (on a field of $4 \times 4=16$ squares), which corresponded to the area of $0.5 \times 0.5 \mathrm{~mm}=$ $0.25 \mathrm{~mm}^{2}$. The results are presented in Tables II, III and IV.

Statistical analysis. The frequency of a specific feature was included in the statistical analysis. For assessing correlations between variables, the Spearman rank coefficient (R) was used. Relationships between categorized variables were assessed using the Pearson's $\chi^{2}$ method. Relationships between 
Table I. Prevalence of HPV DNA in the study groups.

\begin{tabular}{|c|c|c|c|c|}
\hline \multirow[b]{3}{*}{ Group } & \multicolumn{3}{|c|}{ Analysis of HPV DNA types } & \multirow[b]{3}{*}{ p-value } \\
\hline & $\begin{array}{l}\text { HPV DNA } \\
33 \text { type }^{\mathrm{a}}\end{array}$ & $\begin{array}{l}\text { HPV DNA } \\
\text { type } 16\end{array}$ & $\begin{array}{l}\text { HPV DNA } \\
\text { type } 18\end{array}$ & \\
\hline & $\mathrm{n}(\%)$ & $\mathrm{n}(\%)$ & $\mathrm{n}(\%)$ & \\
\hline Squamous cell carcinoma $(n=200)$ & $180(90.0)$ & $140(70.0)$ & $60(30.0)$ & $<0.001^{\mathrm{b}}$ \\
\hline Adenocarcinoma $(n=50)$ & $48(96.0)$ & $8(16.0)$ & $40(80.0)$ & $<0.001^{\mathrm{c}}$ \\
\hline Control $(\mathrm{n}=50)$ & $3(6.0)$ & $2(4.0)$ & $1(2.0)$ & \\
\hline
\end{tabular}

${ }^{\mathrm{a} U n i v e r s a l ~ p r i m e r}$. ${ }^{\mathrm{b}}$ Compared to the control: $\chi^{2}=20.085$, $\mathrm{p}<0.001$; Fisher's test $\mathrm{p}<0.001$; ${ }^{\mathrm{c}}$ Compared to the control: $\chi^{2}=26.421$, $\mathrm{p}<0.001$; Fisher's test $\mathrm{p}<0.001$

Table II. Comparison of individual clinical parameters and expression of estrogen and progesterone receptor protein in the examined groups of patients.

\begin{tabular}{|c|c|c|c|c|c|c|}
\hline \multirow{3}{*}{$\begin{array}{l}\text { Group } \\
\text { Control group }(n=50)\end{array}$} & \multirow{3}{*}{$\begin{array}{c}\text { HPV DNA } \\
\begin{array}{c}(10-50 \% \text { cells } \\
\text { with expression }) \\
\mathrm{n}(\%)\end{array} \\
3(6)\end{array}$} & \multicolumn{2}{|c|}{ ER expression } & \multicolumn{3}{|c|}{ PR expression } \\
\hline & & $\begin{array}{c}\text { Carcinoma } \\
\mathrm{n}(\%)\end{array}$ & $\begin{array}{c}\text { Stromal cells } \\
\mathrm{n}(\%)\end{array}$ & $\begin{array}{l}\text { Carcinoma } \\
\mathrm{n}(\%)\end{array}$ & \multicolumn{2}{|c|}{$\begin{array}{c}\text { Stromal cells } \\
\mathrm{n}(\%)\end{array}$} \\
\hline & & + & ++ & + & ++ & \\
\hline \multicolumn{7}{|l|}{ Case groups } \\
\hline \multirow[t]{5}{*}{$\operatorname{SCC}(n=200)$} & $180(90)$ & & & & & \\
\hline & & $-\quad 90(95)$ & $-\quad 97(48.5)$ & $194(97)$ & - & $89(44.5)$ \\
\hline & & $+10(5)$ & $+\quad 75(37.5)$ & $6 \quad(3)$ & + & $68(34.0)$ \\
\hline & & ++ & $++\quad 18 \quad(9.0)$ & +++ & ++ & $21(10.5)$ \\
\hline & & +++ & +++ $10 \quad(5.0)$ & +++ & +++ & $22(11.0)$ \\
\hline \multirow[t]{5}{*}{ Adenocarcinoma $(\mathrm{n}=50)$} & $48(96)$ & & & & & \\
\hline & & $-\quad 47(94)$ & $29(58.0)$ & $48(96)$ & - & $30(60.0)$ \\
\hline & & $3(6)$ & $+\quad 16(32.0)$ & $2(4)$ & + & $15(30.0)$ \\
\hline & & ++ & $++\quad 3(6.0)$ & ++ & ++ & $3(6.0)$ \\
\hline & & +++ & $+++\quad 2(4.0)$ & +++ & +++ & $2(4.0)$ \\
\hline \multicolumn{7}{|l|}{ FIGO classification $^{a}$} \\
\hline \multirow[t]{4}{*}{$\mathrm{I}(\mathrm{n}=150)$} & $140(93)$ & -133 & 73 & 135 & - & \\
\hline & & +10 & 47 & + & + & 50 \\
\hline & & ++ & ++ & ++ & ++ & 18 \\
\hline & & +++ & $+++\quad 8$ & +++ & +++ & 20 \\
\hline \multirow[t]{2}{*}{ II $(n=100)$} & $90(90)$ & $\begin{array}{l}-\quad 87\end{array}$ & $-\quad 51$ & 87 & - & \\
\hline & & + & 44 & + & + & 33 \\
\hline
\end{tabular}

For SCC cases, ER: carcinoma vs stroma cell, $\mathrm{p}=0.023$; PR: carcinoma vs. stroma cell, $\mathrm{p}=0.041, \chi^{2}$ test. For adenocarcinoma cases, ER: carcinoma vs stroma cell, $\mathrm{p}=0.018$; PR: carcinoma vs. stroma cell, $\mathrm{p}=0.015, \chi^{2}$ test. ${ }^{\mathrm{a}}$ Differentiation of the neoplastic process according to the FIGO classification.

variables were also assessed by an agglomeration algorithm, a tree-based method (city distance, full linkage). The range of significance was set at $\mathrm{p}<0.05, \mathrm{p}>0.1$, which was considered to be marginally significant.

\section{Results}

Frequency of HPV DNA. Infection of HPV types 16 and/or 18 was noted in 3 out of $50(6 \%)$ cases in the control group.
HPV DNA was found in 180 out of the 200 (90\%) examined microscopic sections from the patients with squamous cell carcinoma, whereas HPV DNA was noted in 48 of $50(96 \%)$ cases of adenocarcinoma (Table I).

Based on the clinical staging of the cervical cancer (FIGO classification) the DNA of HPV type 16 and/or 18 was detected in 140 of 150 (93\%) grade I cases and in 90 out of $100(90 \%)$ grade II cases. There was no correlation between the prevalence of DNA type 16/18 and clinical grade. Analysis 


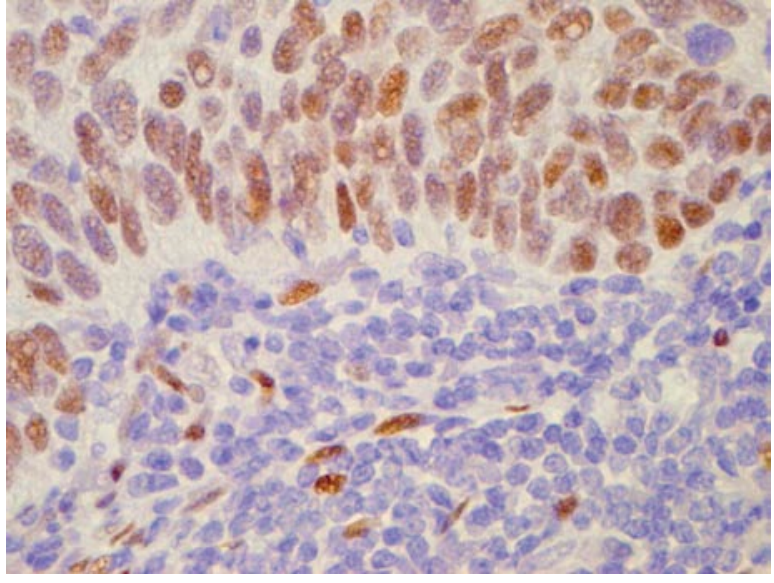

Figure 3. Immunohistochemical staining for ER. Squamous cell carcinoma showing $3+$ positivity, exhibits an intense, nuclear reaction in nearly all of the tumor cells. There is strong staining of the individual stromal cells but negative staining in the lymphocytes. Magnification, $\mathrm{x} 400$.

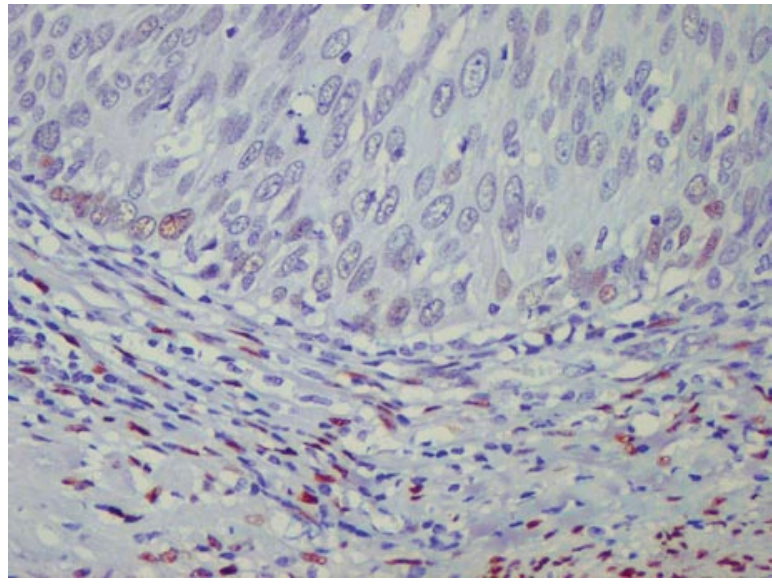

Figure 4. Squamous cell carcinoma showing 1+ positivity for ER. Note the weak staining in the basal layer of the neoplastic tissue and intense staining of the stromal cells. Magnification, x400.

of the correlation between histopathological grade and presence of HPV type 16 and/or 18 DNA revealed the presence of viral DNA in 86 out of $89(96.6 \%)$ GI cases, in 75 out of 78 (96\%) G2 cases, and in 80 out of 83 (96\%) G3 cases. There were no significant differences in the prevalence of HPV DNA in relation to tumor grade (Table II).

Expression of ER and $P R$ protein. In the control group consisting of normal epithelium of the cervix, the expression of ER and PR protein was between 10 and 50\% (Table III). Figs. 3-6 illustrate IHC staining for both receptors.

Squamous cell carcinoma group. In the squamous cell carcinoma cases, the expression of ER (determined according to described standard methods) was absent in 190 of the 200 (95\%) cases. Expression of +1 was found in 10 out of the 200 (5\%) cases, and no expression of +2 nor +3 was detected. No expression of ER protein was noted in 97 of the 200 (48.5\%)

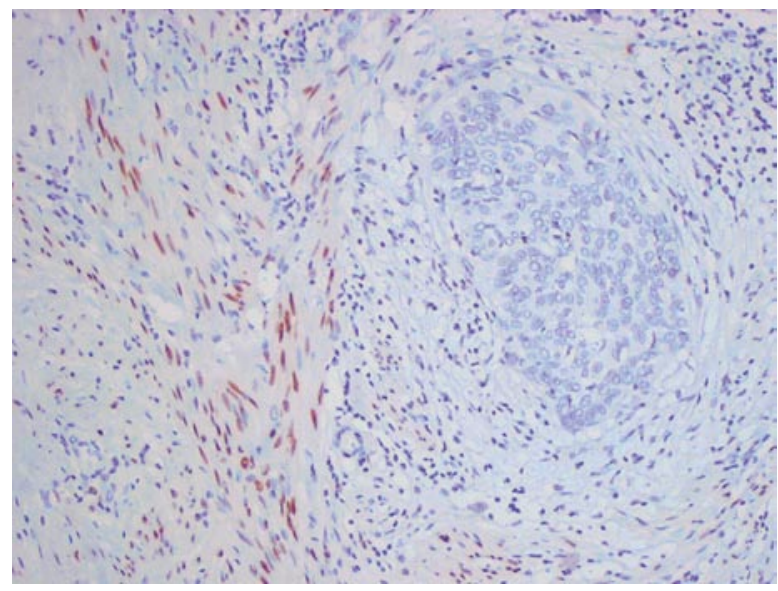

Figure 5. Immunohistochemical staining for PR. In a tumor with negative staining there is no positivity in the tumor cells although staining is present in the scattered stromal cells. Magnification, x200.

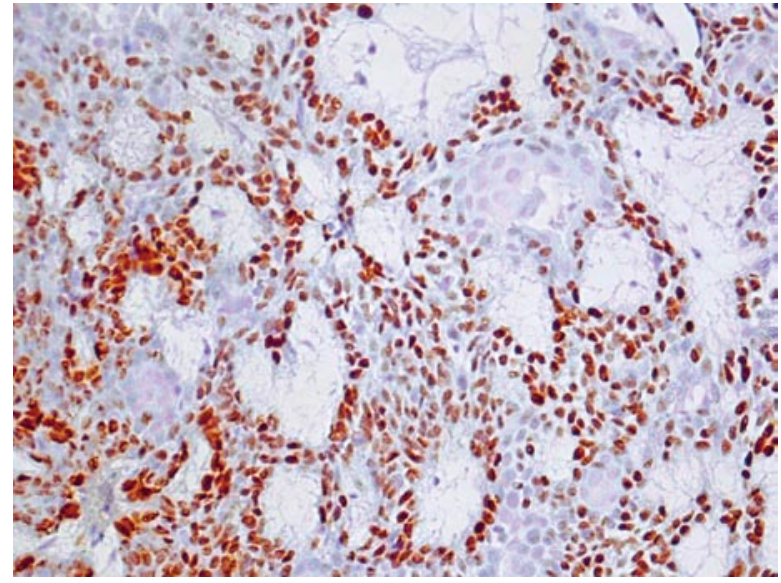

Figure 6. Adenocarcinoma of the uterine cervix with intense positive nuclear immunostaining for PR. Magnification, x200.

stromal cell samples. ER protein expression of +1 was noted in 75 of the $200(37.5 \%)$ cases, +2 in 18/200 (9\%) and +3 in 10 out of $200(5 \%)$.

PR protein expression was absent in 194 out of the 200 (97\%) cases of squamous cell carcinoma while it was evaluated as +1 in only 6 of the $200(3 \%)$ squamous cell carcinoma samples. However, in the stromal cells an absence of PR expression was noted in 89 of the $200(44.5 \%)$ cases, while the expression was assessed as: +1 in 68 out of $200(34 \%),+2$ in 21 out of $200(10.5 \%)$ and +3 in 22 out of $200(11 \%)$ cases. When comparing the difference in expression of the receptors between the staining pattern and stromal cells, the expression levels were statistically significantly higher in the stroma (ER: carcinoma vs. stromal cells, $\mathrm{p}=0.023$; PR: carcinoma vs stromal cells, $\mathrm{p}=0.041 \chi^{2}$ test)

Adenocarcinoma group. Expression of ER (evaluated accordingly to described standard methods) was absent (-) in 47 out of $50(94 \%)$ cases while expression of +1 was noted in 3 out of $50(6 \%)$ cases. ER expression of +2 or +3 was not detected in 
Table III. Number of cells showing expression of estrogen and progesterone receptor proteins.

\begin{tabular}{|c|c|c|c|c|c|c|c|c|}
\hline & $\mathrm{N}$ & Min & Max & M & SD & $10 \%$ & $\mathrm{Me}$ & $75 \%$ \\
\hline ER (no.) & 250 & 48.00 & 256.00 & 168.57 & 61.85 & 72.00 & 180.00 & 224.00 \\
\hline ER (\%) & 250 & 18.75 & 100.00 & 65.85 & 24.16 & 28.13 & 70.31 & 87.50 \\
\hline PR1 (no.) & 250 & 85.50 & 304.00 & 195.07 & 58.55 & 118.75 & 190.00 & 247.00 \\
\hline PR (\%) & 250 & 28.13 & 100.00 & 64.17 & 19.26 & 39.06 & 62.50 & 81.25 \\
\hline
\end{tabular}

no., number of cells showing expression; \%, net area of cells considered positive (+); Min, minimal number of cells showing positive reaction; Max, maximal number of cells showing positive reaction; M, mean value; SD, standard deviation; $10 \%$, in $10 \%$ of watched preparations, expression was observed in the following number of cells; $75 \%$, in $75 \%$ of watched preparations, expression was observed in the following number of cells; Me, median; N, number of cases; ER, estrogen receptor; PR, progesterone receptor.

Table IV. Criteria for evaluation of the reaction to estrogen and progesterone receptor protein expression.

\begin{tabular}{lcc}
\hline $\begin{array}{l}\text { No. of cells } \\
(+) / \text { preparation }\end{array}$ & \% of cells $(+)$ & Reaction \\
\hline Estrogen receptor & $<10$ & \\
$<70$ & $10-50$ & + \\
$72-180$ & $51-75$ & +2 \\
$181-224$ & $>75$ & +3 \\
$>224$ & & \\
Progesterone receptor & $<10$ & - \\
$<70$ & $10-50$ & +1 \\
$118-190$ & $51-75$ & +2 \\
$191-247$ & $>75$ & +3 \\
$>247$ & & \\
\hline
\end{tabular}

$(+)$, with positive expression.

any case. Absence of ER expression was noted in 29 out of 50 (58\%) stromal cell cases while ER expression of +1 was noted in 16 out of $50(32 \%),+2$ in 3 out of $50(6 \%)$ and +3 in 2 out of 50 (4\%) cases. Expression of PR was absent in 48 out of 50 (96\%) adenocarcinoma cases and only 2 cases were evaluated as $+1(4 \%)$. However, in the stromal cells the lack of expression was noted in 30 out of $50(60 \%)$ cases while expression was confirmed as +1 in 15 out of $50(30 \%),+2$ in 3 out of $50(6 \%)$ and +3 in 2 out of $50(4 \%)$ cases.

The difference between the expression of the tested receptors in the pattern of staining and stromal cells was statistically significantly higher in the stroma (ER ca vs. stromal cells, $p=0.018$; $P R$ ca vs. stromal cells, $p=0.015$ ). Based on the IHC results of disease stage I and II (FIGO classification) cases, ER expression was lacking in 133 out of 140 (95\%) cases with stage I clinical grade and in 87 out of 100 (87\%) stage II cases. Higher expression of the tested proteins was found as well in the stromal cells when comparing to the pattern of cancer.

In every stage of histological grading no expression of the studied receptors was found in the stainging patterns of planoepithelial cancer and adenocarcinoma of the uterine
Table V. Spearman rank correlation coefficient $(\mathrm{R})$.

\begin{tabular}{lcc}
\hline Variables & $\mathrm{R}$ & $\mathrm{p}$-value \\
\hline Grade and ER & -0.3241 & 0.4531 \\
Grade and PR & -0.3278 & 0.3216 \\
HPV 16/18 and ER (Ca) & -0.1987 & 0.3156 \\
HPV 16/18 and PR (Ca) & 0.2990 & 0.1050 \\
\hline
\end{tabular}

cervix. Only single cases of expression evaluated as +1 were noted. In the stromal cells, the lack of expression was weakly observable in G1, G2 and G3 but frequently affirmed the existence of tested receptors as $+1,+2$ or +3 (G1: $+1,37$; $+2,10 ;+3,5 ; \mathrm{G} 2:+1,25 ;+2,6 ;+3,4 ; \mathrm{G} 3:+1,10,+2,5 ;+3,3$ for ER and G1: $+1,30 ;+2,8 ;+3,0 ; \mathrm{G} 2:+1,44 ;+2,6 ;+3,4$; G3: $+1,28,+2,10 ;+3,8$ for PR) (Table IV). The analysis of correlations between individual parameters did not show any significant statistical relation for grade and HPV 16/18 status $\left(\chi^{2}=5.128, \mathrm{p}=0.02351\right)($ Table $\mathrm{V})$.

\section{Discussion}

The presence of steroid hormone receptors in normal epithelium and in cervical intraepithelial neoplasia (CIN) was a focus of study in the 1970s (29). A series of reports have shown that the mean ER positivity in cervical mucosa can vary from 13 to $100 \%$. For PRs, this variation is even wider, i.e. $0-100 \%$ of tissues from the uterine cervix has been reported to be PR positive (30-32). No statistically significant correlations have been found for the ER/PR ratio in the cervix when related to menstrual cycle, menopause, histological type or ploidy analysis (30-33).

However, there are reports claiming that the amount of ER and PR can change dynamically during persistent HPV infection (34). Higher levels of estradiol receptor were observed in low-grade CIN tissues from patients who were oral contraceptive users (18), and low expression of ER was observed in CIN II (cervical intraepithelial neoplasia gradus mediocris), while cases of CIN III and ICC (invasive carcinoma of the cervix) were negative for the receptor. Downregulation of ER expression might be the first alteration to 
occur in normal epithelium during the development of cervical dysplasia in women infected with high-risk HPV (35). A study by Fonscesca-Moutinho et al (36) found a significantly higher positive coexpression of ER and PR in CIN III than in CIN II of microinvasive carcinomas of the cervix (MIC). The authors hypothesized that in MIC, most ERs have no or reduced functional activity. This finding was supported by the fact that in MIC with coexpression of ER and PR, the ER staining was stronger and expressed in more cells than PR, which was not true for the CIN III group.

The prognostic significance of $P R$ and ER levels in invasive carcinoma of the cervix (ICC) is controversial. In cervical cancer, increased bcl-2 is generally associated with a better prognosis. Co-expression of ER, PR and bcl-2 may be a useful tool in identifying CIN III lesions with low risk of progression to cervical cancer (36). Potish et al (37) found that premenopausal patients with PR- and ER-positive tumors had a statistically significantly greater survival probability. Nevertheless, this finding did not apply to postmenopausal women. Hunter et al (38), however, found no correlation between ER and PR expression and menopausal status. They also found a weak correlation $(\mathrm{p}=0.063)$ between the presence of PR and length of survival and no correlation between ER status and survival. Nonogaki et al (39) found that the cells in all cases of ICC lost their immunoreactivity to ER, apart from two cases that contained HPV types 31/33/35. This finding led them to suggest that ER expression in ICC may be related to the HPV DNA types and tumor progression.

One major explanation for these discrepancies may be related to the location of the receptors, which can be found either in the epithelium or in stromal cells, at the site of the tissue analyzed, and dependent on the method for receptor detection. In an attempt to clarify some of these issues, the present authors sought to evaluate the concentrations of ER and PR in samples from normal uterine cervix and from invasive carcinoma of the cervix: squamous cell carcinoma and adenocarcinoma of the cervix, associated or not with the presence of DNA HPV.

This study corroborates other research demonstrating an increased grade of malignancy with a decreased number of receptors $(34,39,40)$. The expression of ERs in invasive carcinoma of the cervix can decrease to undetectable levels. The absence of expression in neoplasmic tissues in cervical cancer associated with high-risk HPV does not exclude the influence of estrogen and progesterone on HPV transcription. In recent years, it has been revealed that activated ER can have an effect on DNA, not only through the ER, but also through transcription factor AP-1 (activating protein-1). Transcription complex AP-1 is a dimer composed of factors belonged to the FOS, JUN and MAF families. It plays a crucial role in proliferation and differentiation of epithelial cells. Both types of ERs interact with the AP-1 factor, most frequently with the c-JUN:c-JUN complex in sites of binding (41). However, the influence of each individual type of receptor is dissimilar. Binding of receptor $\alpha$ with $17 \beta$-estradiol activates transcription under the influence of E2 in AP-1, while ER $\beta$ deactivates transcription. Anti-estrogens such as tamoxifen or raloxifen appear to act as agonists of the ER, particularly in the case of $\operatorname{ER} \beta$ (43).
Another method of influence is interaction with the SP-1 protein. Impact of the activation of the SP-1 factor on ER $\alpha$ is independent of the ligand. ER $\alpha$ or $\beta$ create complexes with SP-1 in the promoter of the retinoid acid receptor $\alpha-1$ (RAR1) gene and activate its transcription. The site of binding of SP-1 is rich in sequences GC, therefore the methylation of cytosine in sequences recognized by this factor, neutralize its activated performance $(43,44)$.

One of the biological effects of the activation of ERs is an induction of biosynthesis of PRs. Simultaneously, PR inhibits the creation of ER. The biological effect of estradiol is dependent on PRs. Estradiol induces the expression of PR and achieves its biological function through PR receptors. In the family of nuclear receptors, orphan receptors with no ligands have been discovered. However, recently it has been considered that estrogens might act as ligands (45).

The present study demonstrates that the expression of ER and PR in planoepithelial cancers and adenocarcinomas of the cervix is decreased to undetectable levels. Only in singular cases in the pattern of staining was expression of ER and PR noted. In stromal cells of the studied neoplasms, higher expression of both types of receptors was found. Strong expression $(+1,+2,+3)$ was noted in stromal cells irrespective of the presence of HPV DNA, histopathological type of cancer, and clinical and histopathological grade. Comparison of the presence of the selected receptors (ER and PR) in the staning pattern and stroma in both squamous cell carcinoma and adenocarcioma of the cervix, showed statistically higher expression in stromal cells.

\section{References}

1. Zur Hausen H: Oncogenic DNA viruses. Oncogene 20: 7820-7823, 2001.

2. Smith JS, Lindsay L, Hoots B, et al: Human papillomavirus type distribution in invasive cervical cancer and high-grade cervical lesions: a meta-analysis update. Int J Cancer 121: 621-632, 2007.

3. Mitrani-Rosenbaum S, Tsvieli R and Tur-Kaspa R: Oestrogen stimulates differential transcription of human papillomavirus type 16 in SiHa cervical carcinoma cells. J Gen Virol 70: 2227-2232, 1989.

4. Altekruse SF, Lacey JV Jr, Brinton LA, et al: Comparison of human papillomavirus genotypes, sexual, and reproductive risk factors of cervical adenocarcinoma and squamous cell carcinoma: Northeastern United States. Am J Obstet Gynecol 188: 657-663, 2003.

5. Jayshree RS, Sreenivas A, Tessy M and Krishna S: Cell intrinsic and extrinsic factors in cervical carcinogenesis. Indian J Med Res 130: 286-295, 2009.

6. Chan WK, Klock G and Bernard HU: Progesterone and glucocorticoid response elements occur in the long control regions of several human papillomaviruses involved in anogenital neoplasia. J Virol 63: 3261-3269, 1989.

7. Pittayakhajonwut D and Angeletti PC: Viral trans-factor independent replication of human papillomavirus genomes. Virol J 7: 123, 2010.

8. Bromberg-White JL and Meyers C: The upstream regulatory region of human papillomavirus type 31 is insensitive to glucocorticoid induction. J Virol 76: 9702-9715, 2002.

9. Chen YH, Huang LH and Chen TM: Differential effects of progestins and estrogens on long control regions of human papillomavirus types 16 and 18. Biochem Biophys Res Commun 224: 651-659, 1996.

10. Kedzia W, Gozdzicka-Jozefiak A, Kwasniewska A, Schmidt M, Miturski R and Spaczynski M: Relationship between HPV infection of the cervix and blood serum levels of steroid hormones among pre- and postmenopausal women. Eur J Gynaecol Oncol 21: 177-179, 2000. 
11. Kim CJ, Um SJ, Kim TY, et al: Regulation of cell growth and HPV genes by exogenous estrogen in cervical cancer cells. Int J Gynecol Cancer 10: 157-164, 2000.

12. Cogliano V: IARC Monographs on the Evaluation of Carcinogenic Risks to Humans: Human Papillomavirus. International Agency for Research on Cancer. Lyon, 2007.

13. Auborn KJ, Woodworth C, DiPaolo JA and Bradlow HL: The interaction between HPV infection and estrogen metabolism in cervical carcinogenesis. Int J Cancer 49: 867-869, 1991.

14. Remoue F, Jacobs N and Miot V: High intraepithelial expression of estrogen and progesterone receptors in the transformation zone of the uterine cervix. Am J Obstet Gynecol 189: 1660-1655, 2003.

15. Madeleine MM, Daling JR, Schwartz SM, et al: Human papillomavirus and long-term oral contraceptive use increase the risk of adenocarcinoma in situ of the cervix. Cancer Epidemiol Biomarkers Prev 10: 171-177, 2001.

16. Moreno V, Bosch FX, Munoz N, et al: Effect of oral contraceptives on risk of cervical cancer in women with human papillomavirus infection: the IARC multicentric case-control study. Lancet 359: 1085-1092, 2002.

17. Smith JS, Green J, Berrington de Gonzalez A, et al: Cervical cancer and use of hormonal contraceptives: a systematic review. Lancet 361: 1159-1167, 2003.

18. Salazar EL, Sojo-Aranda I, López R and Salcedo M: The evidence for an etiological relationship between oral contraceptive use and dysplastic change in cervical tissue. Gynecol Endocrinol 15: 23-28, 2001.

19. Arbeit JM, Howley PM and Hanahan D: Chronic estrogeninduced cervical and vaginal squamous carcinogenesis in human papillomavirus type 16 transgenic mice. Proc Natl Acad Sci USA 93: 2930-2935, 1996.

20. Chung SH, Wiedmeyer K and Shai A: Requirement for estrogen receptor alpha in a mouse model for human papillomavirusassociated cervical cancer. Cancer Res 68: 9928-9934, 2008.

21. Mosselman S, Polman J and Dijkema R: ER beta: identification and characterization of a novel human estrogen receptor. FEBS Lett 392: 49-53, 1996.

22. Ellmann S, Sticht H, Thiel F, Beckmann MW, Strick R and Strissel PL: Estrogen and progesterone receptors: from molecular structures to clinical targets. Cell Mol Life Sci 66: 2405-2426, 2009.

23. Nilsson S, Mäkelä S, Treuter E, et al: Mechanisms of estrogen action. Physiol Rev 81: 1535-1565, 2001.

24. Cavaillès V: Estrogens and receptors: an evolving concept. Climacteric 5 (Suppl. 2): S20-S26, 2002.

25. Lazari MF, Lucas TF, Yasuhara F, et al: Estrogen receptors and function in the male reproductive system. Arq Bras Endocrinol Metabol 53: 923-933, 2009.

26. Scarpin KM, Graham JD, Mote PA and Clarke CL: Progesterone action in human tissues: regulation by progesterone receptor (PR) isoform expression, nuclear positioning and coregulator expression. Nucl Recept Signal 7: e009, 2009.

27. Tavassoéli FA and Devilee P: World Health Organization Classification of Tumors: Pathology and Genetics. Tumors of the Breast and Female Genital Organs. IARC Press, Lyon, 2003.

28. Benedet JL, Bender H, Jones H III, Ngan HY and Pecorelli S: FIGO staging classifications and clinical practice guidelines in the management of gynecologic cancers. FIGO Committee on Gynecologic Oncology. Int J Gynaecol Obstet 70: 209-262, 2000 .
29. Bloch B: Hormone receptors in cervical intraepithelial neoplasia. Obstet Gynecol Surv 34: 868-869, 1979.

30. Monsonego J, Magdelenat H, Catalan F, Coscas Y, Zerat L and Sastre X: Estrogen and progesterone receptors in cervical human papillomavirus-related lesions. Int J Cancer 48: 533-539, 1991.

31. Kim JW, Sung HR, Kim DK and Song CH: Estrogen and progesterone receptor assay in carcinoma of the cervix with monoclonal antibodies. Gynecol Oncol 47: 306-310, 1992.

32. Masood S, Rhatigan RM, Wilkinson EW, Barwick KW and Wilson WJ: Expression and prognostic significance of estrogen and progesterone receptors in adenocarcinoma of the uterine cervix. An immunocytochemical study. Cancer 72: 511-518, 1993.

33. González Sánchez JL, Chávez Brambila J, Maricela Román A, Infante Martínez R and Salazar Esquivel LE: Value of estrogen and progesterone receptors in the management of intraepithelial squamous lesions of low grade. Ginecol Obstet Mex 69: 1-5, 2001.

34. Moodley J: Combined oral contraceptives and cervical cancer. Curr Opin Obstet Gynecol 16: 27-29, 2004.

35. Bekkers RL, van der Avoort IA, Melchers WJ, Bulten J, de Wilde PC and Massuger LF: Down regulation of estrogen receptor expression is an early event in human papillomavirus infected cervical dysplasia. Eur J Gynaecol Oncol 26: 376-382, 2005.

36. Fonseca-Moutinho JA, Cruz E, Carvalho L, et al: Estrogen receptor, progesterone receptor, and bcl-2 are markers with prognostic significance in CIN III. Int J Gynecol Cancer 14: 911-920, 2004.

37. Potish RA, Twiggs LB, Adcock LL, Prem KA, Savage JE and Leung BS: Prognostic importance of progesterone and estrogen receptors in cancer of the uterine cervix. Cancer 58: 1709-1713, 1986.

38. Hunter RE, Longcope C and Keough P: Steroid hormone receptors in carcinoma of the cervix. Cancer 60: 392-396, 1987.

39. Nonogaki H, Fujii S, Konishi I, Nanbu Y, Ozaki S, Ishikawa Y and Mori T: Estrogen receptor localization in normal and neoplastic epithelium of the uterine cervix. Cancer 66: 2620-2627; 1990.

40. Coelho FR, Prado JC, Pereira Sobrinho JS, et al: Estrogen and progesterone receptors in human papilloma virus-related cervical neoplasia. Braz J Med Biol Res 37: 83-88, 2004.

41. Teyssier C, Belguise K, Galtier F and Chalbos D: Characterization of the physical interaction between estrogen receptor alpha and JUN proteins. J Biol Chem 276: 36361-36369, 2001.

42. Levy N, Tatomer D, Herber CB, et al: Differential regulation of native estrogen receptor-regulatory elements by estradiol, tamoxifen, and raloxifene. Mol Endocrinol 22: 287-303, 2008.

43. Saville B, Wormke M, Wang F, et al: Ligand-, cell-, and estrogen receptor subtype (alpha/beta)-dependent activation at GC-rich (Sp1) promoter elements. J Biol Chem 275: 5379-5387, 2000.

44. Safe S and Kim K: Non-classical genomic estrogen receptor (ER)/specificity protein and ER/activating protein-1 signaling pathways. J Mol Endocrinol 41: 263-275, 2008.

45. Rae JM and Johnson MD: What does an orphan G-proteincoupled receptor have to do with estrogen? Breast Cancer Res 7: 243-244, 2005. 